\title{
Soil erosion, runoff and nutrient losses in an avocado (Persea americana Mill) hillside orchard under different groundcover management systems
}

\author{
Amaya Atucha • Ian A. Merwin • Michael G. Brown • \\ Francisco Gardiazabal • Francisco Mena • Cecilia Adriazola • \\ Johannes Lehmann
}

Received: 23 July 2012 / Accepted: 30 October 2012 / Published online: 17 November 2012

(C) The Author(s) 2012. This article is published with open access at Springerlink.com

\begin{abstract}
Aims Assess the influence of different groundcover management systems on erosion and runoff processes associated with extremely steep hillside avocado (Persea americana Mill) orchards, in a Mediterranean climate with high rainfall variability.

Methods We compared several groundcover management systems at a steep hillside avocado planting in a three-year study: 1) Bare soil (BS), pre- and post-
\end{abstract}

Responsible Editor: Johan Six.

A. Atucha $(\bowtie)$

Department of Horticulture and Landscape Architecture,

Western Colorado Research Center,

Colorado State University,

3168 B 1/2 Road,

Grand Junction, CO 81503, USA

e-mail: amaya.atucha@colostate.edu

I. A. Merwin · M. G. Brown

Department of Horticulture, Cornell University,

134A Plant Science Building,

Ithaca, NY 14853, USA

F. Gardiazabal · F. Mena $\cdot$ C. Adriazola

Sociedad Gardiazabal \& Mena,

Blanco 512,

Quillota, V Region, Chile

J. Lehmann

Department of Crop and Soil Sciences, Cornell University, 909 Bradfield Hall,

Ithaca, NY 14853, USA emergence herbicides; 2) Vegetation strip (VS), postemergence herbicide applied in a 1-m wide strip on the tree row plus groundcover seeded between tree rows; 3) Groundcover (GC), over the entire plot surface.

Results Trees in the BS plots were 44 and $53 \%$ bigger, and had 150 and $250 \%$ higher yields than trees in VS and GC, respectively. Runoff volumes, soil losses, dissolved organic carbon, $\mathrm{PO}_{4}-\mathrm{P}$ and total $\mathrm{N}$ losses were significantly higher in BS than VS and CG treatments. Total soil nitrogen $(\mathrm{N})$ and carbon $(\mathrm{C})$ content, $\mathrm{C}$-to-N ratios, and essential plant nutrient availability were greater in the GC soil than in other treatments. Soil macroporosity and aggregate stability were 8 $27 \%$ and $25 \%$ lower, and soil bulk density significantly higher in the BS than the VS and GC systems at the end of the study. Terbuthylazine herbicide concentrations in runoff water from BS plots ranged from 55.4 to $79.9 \mu \mathrm{gL}^{-1}$, exceeding maximum allowed levels for drinking water $\left(0.1 \mu \mathrm{gL}^{-1}\right)$.

Conclusion Soil erosion and runoff rates from newly planted hillside orchards are not environmentally sustainable under current growing practices where groundcover vegetation is completely suppressed. High sediment losses and herbicide residues in runoff water present serious risk of water source pollution, but these impacts can be reduced by alternative soil management systems.

Keywords Erosion control · Runoff · Nutrient loss · Water quality $\cdot$ Groundcover management system 


\section{Introduction}

Increasing land prices and urban expansion into agricultural valley regions in central Chile have constrained avocado (Persea americana Mill) orchards to marginal soil and steep hills, where other crops have been impractical (Geo-Chile 2005). Potential environmental problems associated with hillside avocado production include increased erosion and runoff when native vegetation is removed from hillsides, and herbicide applications eliminate groundcover vegetation. Herbicides and fertilizers in hillside runoff water may also impact the quality of water consumed by humans and livestock in downslope areas (Pimentel et al. 1995). There are no previous studies evaluating the environmental impacts of extremely steep hillside orchards.

Site preparation for establishing hillside avocado plantations in Chile begins with removal of all native vegetation in the area to be planted, and excavating the underlying soil into raised berms where avocado trees will be planted parallel to the slope. The bermed soil remains loose and vulnerable to wind or water erosion. The ditched channels between berms concentrate runoff and provide few obstacles to rapid outflows down the hillsides on occasions when there are intense rainfalls (Youlton et al. 2010). The climate in avocado growing regions of Central Chile is Mediterranean type, strongly influenced by the Southern Oscillation, causing El Niño and La Niña events with alternate multiyear cycles of torrential and low rainfall events (CONAMA 2006; Gasto et al. 1987). After avocado trees are established, the conventional soil groundcover management consists of residual pre- and postemergence herbicide applications to eliminate weeds and avoid competition for water and nutrients. In the short-term these hillside plantings have been productive and profitable, but the potential long-term soil losses and runoff volumes generated from these orchards are unknown, and there are no data on potential water contamination from nutrient losses and herbicide residues in exported sediments and runoff water from such plantings.

Several studies in hillside Mediterranean orchards and vineyards have reported impacts of vegetationfree groundcover management systems on soil loss and runoff (Cerda et al. 2009; Gomez et al. 2004; Francia Martínez et al. 2000; Tropeano 1983; Uson et al. 1998; Francia Martinez et al. 2006), as well as the benefits of groundcover vegetation for reducing soil erosion and runoff from these orchards (Toscano et al. 2004; Novara et al. 2011; Martinez Raya et al. 2006; Kosmas et al. 1996; Francia Martínez et al. 2000). However, the risk of competition for water and nutrients between groundcovers and fruit trees and decreased yields has made fruit growers reluctant to change their weed-free soil management systems (Gomez et al. 2004). This paper contributes to the knowledge of how to control soil losses and runoff from very steep hillside orchards, and the impacts these management practices have on tree growth and yield.

Off-site movement of nutrients and pesticide residues in runoff is a well-documented source for pollution of surface and groundwater (Sims et al. 1998; Glotfelty et al. 1984; Leonard 1990; Braun and Hawkins 1991; Simmons and Leyva 1994). Nonetheless, there are few reports on the effects that groundcover management systems have on the load of nutrient and herbicide residues exiting high input perennial cropping systems established on steep hillsides. The removal of all native vegetation from very steep hillsides, construction of downslope berms, and high inputs of fertilizers and herbicides to successfully establish these avocado orchards have potential impacts that require further study.

The present study was conducted to compare the effects of different groundcover management systems on runoff and erosion at a representative hillside avocado plantation, to quantify nutrient losses and herbicide residues in runoff water, and to evaluate the effects of different groundcover management systems on tree growth, nutrition and production, and soil physical properties.

\section{Materials and methods}

\section{Experimental site}

The experimental site is a 0.75 ha plot with $47 \%$ slope located at the edge of a 300 ha hillside avocado orchard in Panquehue, Central Chile (Latitude $32^{\circ} .49^{\prime}$ 25.94" S, Longitude 70 ${ }^{\circ} 55^{\prime} 56.04^{\prime \prime} \mathrm{W}$ ). The soil type at this site is dominated by Andisols, based upon textural ratios determined by fractional sedimentation (Table 1). The site was prepared for planting in 2007 , by removing all native vegetation from the 
Table 1 Characteristics of the soil in each replicate block prior to the establishment of treatments. Soil particle size distribution was based on the USDA system. OM = soil organic matter content; total $\mathrm{N}$ and total $\mathrm{C}$ based on Dumas combustion analysis; slope (\%)

\begin{tabular}{llllllll}
\hline Block & Clay $\left(\mathrm{g} \mathrm{kg}^{-1}\right)$ & Silt $\left(\mathrm{g} \mathrm{kg}^{-1}\right)$ & Sand $\left(\mathrm{g} \mathrm{kg}^{-1}\right)$ & $\mathrm{OM}\left(\mathrm{g} \mathrm{kg}^{-1}\right)$ & Total N $\left(\mathrm{mg} \mathrm{g}^{-1}\right)$ & $\mathrm{Total} \mathrm{C}\left(\mathrm{mg} \mathrm{g}^{-1}\right)$ & $\mathrm{S}$ Slope $(\%)$ \\
\hline B1 & 142.9 & 349.9 & 507.2 & 3.1 & 0.5 & 6.9 & 52 \\
B2 & 132.6 & 334.1 & 533.3 & 2.4 & 0.5 & 5.0 & 49 \\
B3 & 134.9 & 269.5 & 595.6 & 2.6 & 0.6 & 9.7 & 32 \\
B4 & 189.6 & 270.1 & 540.3 & 3.2 & 0.8 & 8.9 & 54 \\
B5 & 201.5 & 330.4 & 468.0 & 3.1 & 0.7 & 48 \\
\hline
\end{tabular}

hillside with an excavator. Berms approximately $50 \mathrm{~m}$ long and $1 \mathrm{~m}$ high were constructed in Dec. 2007, gathering the soil from the inter-rows into raised berms for the planting rows (Fig. 1). Avocado trees ('Hass' on 'Mexicola' seedling rootstocks) were planted on the berm-rows in Aug. 2008, at $2 \times 5 \mathrm{~m}$ spacing. The irrigation system consisted of one line of drippers for each berm row, with each orifice emitting
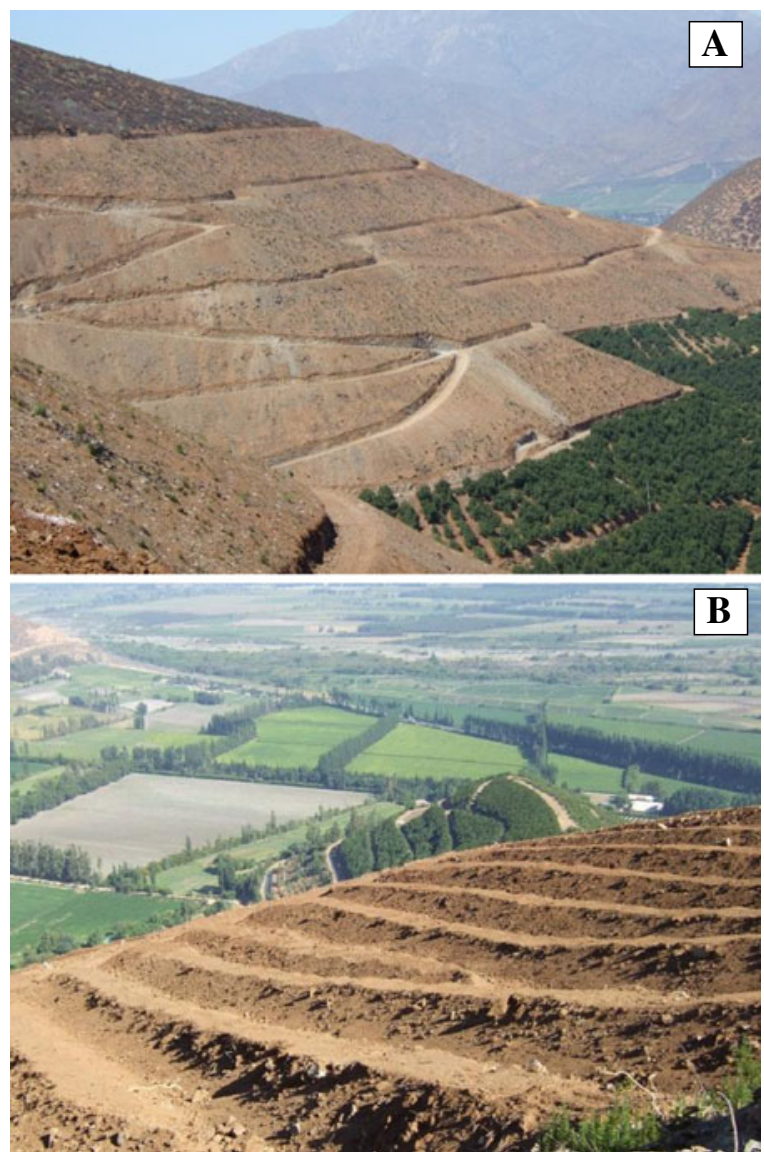

Fig. 1 a Hillside after the removal of native vegetation; b Raised berms parallel to the slope, prior to planting avocados
$4 \mathrm{Lhr}^{-1}$ through two drippers about $0.2 \mathrm{~m}$ above and below each tree. A supplemental line of microsprinklers provided $34 \mathrm{~L} \mathrm{hr}^{-1}$ irrigation in the ditches between berms for the establishment of the groundcovers in two of the treatments; this line was shutdown in Dec. 2008, after the groundcovers were fully established. Three groundcover management systems were assigned randomly to 15 plots, with five blocks containing one replicate of each treatment per block. The experimental units were $10-\mathrm{m}$ wide across the slope and 50-m long down the slope; each plot included two parallel tree berm-rows with 20 to 25 trees, separated by a $5-\mathrm{m}$ wide ditch between the berm-rows.

\section{Groundcover management systems}

Three treatments were established in Aug. 2008, and maintained as follows: 1) Bare soil (BS) - a combination of two herbicides (glyphosate and terbuthylazine) was applied over the entire plot surface (berms and ditches), at 1.44 and $3.0 \mathrm{~kg}$ active ingredient (a.i.) $\mathrm{ha}^{-1}$, respectively. Terbuthylazine was applied in Aug. 2008, June 2009 and May 2010. Glyphosate was applied in Aug. 2008 and 2009, and in June 2010; 2) Vegetation strip (VS) - post-emergence glyphosate applied in a 1-m wide strip centered on the tree berm-row at a rate of $1.44 \mathrm{~kg}$ a.i. ha ${ }^{-1}$, but not to the inter-row ditches, during Aug. 2008 and 2009, and May 2010, to suppress weeds during the growing season. In Aug. 2008 a mixture of ryegrass (Lolium rigidum var. wimmera) and the naturalized burr-clover Hualputra (Medicago polymorpha sp.) was seeded in the ditches between the VS berm-rows at a rate of 75 and $30 \mathrm{kgha}^{-1}$, respectively. During Aug. 2009 this groundcover mixture was suppressed with a contact herbicide (paraquat) applied at a rate of $0.9 \mathrm{~L}$ a.i. $\mathrm{ha}^{-1}$. During Feb. 2010 this groundcover was mowed to 0.1$\mathrm{m}$ height using a weed trimmer, to prevent possible 
brush fires during the summer; 3) Complete groundcover (GC) - the same mixture of ryegrass (Lolium rigidum var. wimmera) and Hualputra (Medicago polymorpha $s p$.) as in the VS treatment, established in Aug. 2008, covering the entire surface of plots (bermrows and ditches) and mowed to 0.1-m height during Feb. 2009 and 2010, with residues left on site.

Orchard management

The avocado trees were managed as is typically done for hillside commercial orchards in central Chile (Gardiazabal 1998). Trees were fertigated each year, applying $120-250 \mathrm{Kg} \mathrm{ha}^{-1}$ of $\mathrm{N}, 50 \mathrm{Kg} \mathrm{ha}^{-1}$ of $\mathrm{K}$, and $50-80 \mathrm{Kg} \mathrm{ha}^{-1}$ of P.

\section{Erosion measurement plots}

Fifteen runoff/erosion catchment plots ( $25 \mathrm{~m}$ long by $5 \mathrm{~m}$ wide), consisting of two berm-rows and one ditch between the berm-rows, were established during Fall of 2008 , just before trees were planted. At the lower end of each catchment a plywood weir was constructed to channelize sediments and runoff through a polyvinyl chloride (PVC) pipe, into a 120-L high density polyethylene (HDPE) barrel secured by four metal posts driven $1 \mathrm{~m}$ into the ground. Outflows from the barrels were measured with tipping buckets attached to a HOBO Data Logger model UA-003-64 (Onset Technologies, Bourne, Mass.) to record the number of calibrated tips and measure overflows when the barrels were full. This system enabled us to measure continuous outflows of water from each plot during each rain event, over 3 years. To estimate soil losses, a water sample was taken from each barrel following precipitation events, after stirring the water in barrels to bring sediments into suspension. Samples were filtered through Whatman Glass Microfibre Filter paper (Fisher Scientific, N.H.), sediments were oven-dried at $40{ }^{\circ} \mathrm{C}$ for several days to constant weight, and sediment dry weights were recorded for each sample.

Data-logging soil moisture and temperature

Soil moisture monitoring probes were installed in each plot for continuous datalogging. Volumetric soil water content and temperature at $0.05-\mathrm{m}$ depth in soil were recorded using EC-TM (moisture-temperature) sensors (Decagon Devices, Wash.) logged with Em50 five-port data-logger (Decagon Devices, Wash.). This enabled us to record data at bi-hourly intervals continuously year-round from all 15 plots. Volumetric soil water content data were averaged biweekly for each plot to facilitate trends interpretation and presentation. When soil-monitoring data were lost due to transient technical problems, missing values were estimated by extrapolating from averages of comparable time intervals for other plots at the site.

Tree growth and fruit yield

Tree-trunk cross-sectional area (TCSA) was recorded annually during the winter season (July-August) at a permanently marked height ( $0.3 \mathrm{~m}$ above ground $)$ to estimate annual and cumulative increases in tree size. Fruit yield was recorded in 2011, as harvested fruit weight $(\mathrm{kg})$ per tree, number of fruit per tree and average fruit size. During 2008, TCSA was recorded for all trees in each plot. However, during 2009 several trees had to be replaced in the GC plots due to hare (Lepus europaeus) damage to the lower tree trunks. TCSA and yield data were collected from the centermost 15 healthy trees in each plot (to minimize edge effects) and averaged to represent a treatment mean for respective treatments. During 2011, subsamples of ten fruits per tree were individually weighed to estimate fruit size distribution. Yield efficiency of the trees in each treatment was calculated by dividing fruit yield $\left(\mathrm{kg}\right.$ tree $\left.{ }^{-1}\right)$ by TCSA $\left(\mathrm{cm}^{2}\right)$.

\section{Leaf nutrient content}

Recently matured leaves were sampled in July from the centermost 15 trees in each plot (Lahav and Whiley 2002). Leaves were rinsed with distilled water and oven-dried at $40{ }^{\circ} \mathrm{C}$ for several days to constant weight. Samples were digested with hydrogen peroxide and dried ash for $2 \mathrm{~h}$ at $450{ }^{\circ} \mathrm{C}$ and analyzed for macroand micro-nutrient concentrations by inductively coupled Argon plasma spectroscopy (ICP AES model Spectro CIROS vision, Kleve, Germany); leaf C and N content was determined by Dumas combustion methods.

Water analysis for nutrient concentrations and herbicide residues

After each precipitation event, water samples were collected in HDPE bottles from each barrel by stirring 
the water and sediments to obtain a homogeneous sample. Samples were filtered through Whatman Glass Microfibre Filter paper (Fisher Scientific, N.H.) and frozen at $-5{ }^{\circ} \mathrm{C}$ for subsequent analyses of $\mathrm{N}$ and $\mathrm{P}$ concentrations, using an automated cadmium reduction method and ascorbic acid method, respectively (Clesceri et al. 1998) followed by continuous-flow colorimetry (Perstorp Analytical, Alpkem, Ore.). Each runoff sample was analyzed for herbicide residues. Terbuthylazine analyses were carried out using enzyme-linked immunosorbent assay (ELISA) kits (Strategic Diagnostics Inc., Newark, DE) with minimum detection limits of $0.31 \mu \mathrm{gL}^{-1}$ for terbuthylazine. Concentrations were determined spectrophotometrically (at $450 \mu \mathrm{m}$ ) in a dedicated RPA-1 spectrophotometer.

\section{Soil nutrient availability}

Soil samples were collected during mid-winter from 2009 to 2011 with a 0.02 -m-diam metal core, from 0 to $0.1-\mathrm{m}$ depth beneath tree canopies along the bermrows. Samples were sent to the Cornell Nutrient Analysis Lab (CNAL) and analyzed for plant available nutrients as follows. Macro- and micronutrients were extracted in Morgan's solution $(0.72 \mathrm{~N} \mathrm{NaOAc}+0.52 \mathrm{~N}$ $\mathrm{CH}_{3} \mathrm{COOH}$, buffered at $\mathrm{pH} 4.8$ ), using a soil-tosolution ratio of 1:5 (v/v). The extracted mixture was filtered and passed through an automated rapid flow analyzer to detect plant-available $\mathrm{PO}_{4}-\mathrm{P}$, while the rest of the bases and micronutrients were quantified by inductively coupled argon plasma (ICP) spectrophotometry. Soil $\mathrm{pH}$ was determined using 1:1 (v/v) soil to $0.01 \mathrm{M} \mathrm{CaCl}_{2}$ solution, and total $\mathrm{C}$ and $\mathrm{N}$ by Dumas combustion. Soil organic matter was determined by loss on ignition at $550{ }^{\circ} \mathrm{C}$.

\section{Physical soil properties}

Intact core samples were collected using two stainless steel cores taped vertically together, for a $0.07-\mathrm{m}$ internal diameter and a 0.12-m depth. Cores were driven into the soil and lifted out with a hand-shovel to minimize changes to field soil conditions during extraction. The cores were evaluated for soil bulk density, porosity and available water capacity, using procedures described by Moebius et al. (2007), Moebius-Clune et al. (2008) and Karunatilake and van Es (2002). Undisturbed samples were prepared for analysis by carefully separating the taped cores into upper and lower profiles, which represented 0 $0.06 \mathrm{~m}$ and $0.06-0.12 \mathrm{~m}$ soil depth, respectively. Nylon gauze was attached to the bottom of each ring with a rubber band to prevent soil loss. Soil sample cores were saturated $(\Psi=0 \mathrm{kPa})$ in their rings by raising the water table slowly during $48 \mathrm{~h}$ to prevent trapping air in soil pores. Macroporosity (pores of diameter $>1,000 \mu \mathrm{m}$ ) was determined gravimetrically by allowing the saturated cores to drain for $3 \mathrm{~h}$, to reach an assumed equilibrium water potential at $\Psi=$ $-0.3 \mathrm{kPa}$. A pressure-cell apparatus was used to determine soil water retention at $-1.0,-3.0,-10.0$ and $-30.0 \mathrm{kPa}$ matric potentials. Soil cores were then oven-dried at $105{ }^{\circ} \mathrm{C}$ and weighed to determine bulk density. Available water capacity $\left(\mathrm{m}^{3} \mathrm{~m}^{-3}\right)$ was calculated as the difference in water loss between $\Psi=-10.0$ and $\Psi=-1,500 \mathrm{kPa}$. Wet aggregate stability of small aggregates $(0.25-2 \mathrm{~mm}$ ) was measured from disturbed samples using a rainfall simulator (Ogden et al. 1997). Samples were oven-dried at $40{ }^{\circ} \mathrm{C}$ and shaken over stacked $2 \mathrm{~mm}$ and $0.25 \mathrm{~mm}$ mesh sieves and a catch plate. A single layer of 0.25 to $2 \mathrm{~mm}$ aggregates was spread on a $0.25 \mathrm{~mm}$ mesh sieve and placed $0.5 \mathrm{~m}$ below a rain simulator, calibrated to delivered $12.5 \mathrm{~mm}$ of water in $5 \mathrm{~min}$. Soil and other particles retained on the sieve and disaggregated soil that fell through the sieve onto a filter were collected, dried, and weighed to determine wet aggregate stability.

\section{Precipitation record}

During 2008, rainfall amounts were recorded by a standard tubular rain gauge located at the bottom of the hillside. During 2009 and 2010, precipitation amounts and rates were recorded by a RAINEW-111 rain gauge (Premiere Products, Columbus, NE), logged with HOBO data-loggers. There were two rain gauges at the site, one in the upper and another in the lower rows of plots; data presented are the averages of both rain gauges.

\section{Data analysis}

A repeated measurement model (JMP, Version 7. SAS Institute Inc., Cary, N.C., U.S.) was used to analyze data within years. When there were significant interactions between treatments and years, data were analyzed as a one-way analysis of variance model for each year. When significant effects were indicated means were compared using Tukey's HSD at $P<$ 
0.05 , unless otherwise noted in text and tables. During 2008, groundcover treatments were not fully established during the recorded rain events, and the data collected from all plots were pooled and presented as a baseline record for runoff and erosion rates at the site. For the year 2010, data were analyzed using a logistic regression model to determine if treatments had an effect on the presence or absence of surface runoff, and a one-sample $T$-test was used to determine whether runoff observed in the BS treatment was significantly different from zero.

\section{Results}

Tree growth and fruit yield

During the first 3 years after planting, trees in BS plots were larger than in GC plots (Fig. 2) and also significantly bigger than VS trees in 2010 and 2011. No significant differences were observed between VS and GC in 2010 or 2011. The first avocados were harvested in 2011, 3 years after tree establishment. Trees in the BS plots produced $5 \mathrm{Kg}$ of fruit per tree compared to 2 and $1.3 \mathrm{Kg}$ of fruit per tree in the VS and GC plots, respectively. The numbers of fruit per tree was significantly higher in the BS plots, with and average of 27 fruit per tree, compared to 11 and 7 fruits per tree in the VS and GC plots, respectively. No significant differences were observed for fruit size among the treatments.

\section{Leaf nutrient content}

Although there were significant differences in leaf nutrient content among the treatments in 2009, 2010 and 2011, there were no consistent treatment trends that spanned all 3 years of evaluation. No significant differences were observed in total $\mathrm{N}$ or $\mathrm{C}$ content in avocado leaf tissue among treatments for any of the 3 years, and visible symptoms of nutrient deficiencies were not observed in trees under any treatment.

\section{Runoff, erosion and nutrient losses}

During the first year of this study (2008), the cumulative runoff volume across all plots was $4 \mathrm{~mm}, 3 \%$ of the total precipitation (Table 2). The largest runoff event was recorded during the last rainfall of 2008 $(70 \mathrm{~mm})$, with an average runoff volume across all treatments of $3 \mathrm{~mm}$. Total soil loss averaged across all plots was $3,141 \mathrm{Kg} \mathrm{ha}^{-1}$, and the biggest soil loss was recorded at the first rainfall event of that year $(17 \mathrm{~mm})$, with an average loss across plots of $1.9 \mathrm{Mgha}^{-1}$. The $\mathrm{NH}_{4}{ }^{+}-\mathrm{N}$ and $\mathrm{PO}_{4}{ }^{-}-\mathrm{P}$ concentrations in runoff water were similar for all precipitation events, averaging 0.1 and $0.2 \mathrm{mgL}^{-1}$, respectively. Total nutrient losses were $22.3,13.1,55.4$ and $59.3 \mathrm{gha}^{-1}$ of inorganic-N, $\mathrm{PO}_{4}-\mathrm{P}, \mathrm{TN}$, and DOC, respectively (Table 2).

During 2009, runoff volumes, sediment losses, and $\mathrm{PO}_{4}-\mathrm{P}, \mathrm{TN}$ and DOC losses were significantly greater from the BS plots than the VS and CG treatments, with no significant differences between the latter two treatments (Table 2). During the most intense rainfall event on 28 June $(58.9 \mathrm{~mm})$, the BS plots generated $1.3 \mathrm{~mm}$ of runoff and $758.8 \mathrm{Kg} \mathrm{ha}^{-1}$ of soil loss. During five rainfall events observed in 2009, the GC plots only produced detectable runoff in the first three rains.

In the winter of 2010 , three precipitation events occurred. The two treatments with groundcover
Fig. 2 Cumulative mean of avocado (Persea americana Mill) tree Trunk Cross Sectional Area (TCSA) $\left(\mathrm{cm}^{2}\right)$ from 2008 through 2011. Letters of mean separation were generated from Tukey's HSD test at $P \leq 0.05$

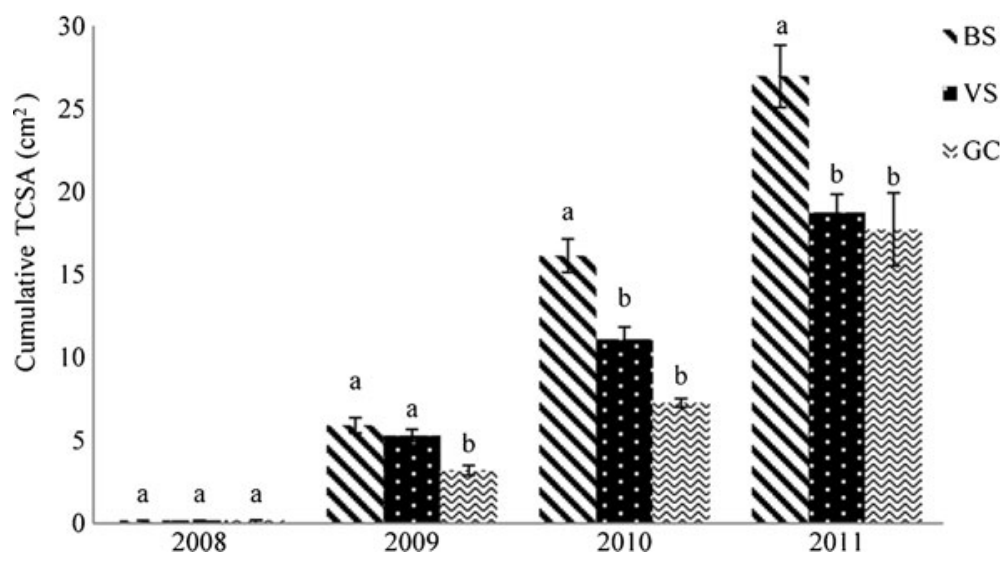


Table 2 Precipitation (Prcp), runoff, soil losses, and ammonium-N $\left(\mathrm{NH}_{4}-\mathrm{N}\right)$, nitrate- $\mathrm{N}\left(\mathrm{NO}_{3}-\mathrm{N}\right)$, phosphate-P $\left(\mathrm{PO}_{4}^{-}\right.$ $\mathrm{P})$, total $\mathrm{N}(\mathrm{TN})$, and dissolved organic carbon (DOC) losses in runoff water collected annually in each groundcover management system. There was no recorded runoff in the GC and VS plots during 2010

Date Treatments Prcp (mm) Runoff (mm) Soil loss $\left(\mathrm{Kg} \mathrm{ha}^{-1}\right)$ Nutrient losses by runoff

$\begin{array}{llll}\text { Inorganic-N }\left(\mathrm{g} \mathrm{ha}^{-1}\right) \quad \mathrm{P}\left(\mathrm{g} \mathrm{ha}^{-1}\right) & \mathrm{TN}\left(\mathrm{g} \mathrm{ha}^{-1}\right) & \mathrm{DOC}\left(\mathrm{g} \mathrm{ha}^{-1}\right)\end{array}$

\begin{tabular}{|c|c|c|c|c|c|c|c|c|}
\hline \multirow{2}{*}{$\begin{array}{l}2008 \\
2009\end{array}$} & & 118.5 & 3.64 & 3140.5 & 22.3 & 13.1 & 55.4 & 59.3 \\
\hline & & & & & & & & \\
\hline \multirow[t]{3}{*}{$6 / 19$} & BS & 36.3 & $0.05 \pm 0.03$ & $2.7 \pm 1.5$ & $7.4 \pm 3.7$ & $0.5 \pm 0.2$ & $10.0 \pm 4.0$ & $3.1 \pm 1.9$ \\
\hline & VS & & $0.02 \pm 0.00$ & $0.3 \pm 0.1$ & $1.4 \pm 0.6$ & $0.3 \pm 0.1$ & $2.2 \pm 0.7$ & $1.8 \pm 0.6$ \\
\hline & $\mathrm{GC}$ & & $0.01 \pm 0.00$ & $0.1 \pm 0.0$ & $2.4 \pm 1.1$ & $0.1 \pm 0.0$ & $3.3 \pm 1.1$ & $1.1 \pm 0.5$ \\
\hline \multirow[t]{3}{*}{$6 / 28$} & BS & 58.9 & $1.30 \pm 0.71$ & $758.8 \pm 463.5$ & $4.6 \pm 2.9$ & $6.9 \pm 3.8$ & $15.6 \pm 8.4$ & $53.1 \pm 27.2$ \\
\hline & VS & & $0.16 \pm 0.09$ & $3.1 \pm 1.9$ & $1.9 \pm 0.5$ & $1.2 \pm 0.7$ & $3.3 \pm 1.3$ & $21.1 \pm 11.9$ \\
\hline & $\mathrm{GC}$ & & $0.02 \pm 0.00$ & $0.3 \pm 0.1$ & $1.5 \pm 0.4$ & $0.2 \pm 0.0$ & $2.0 \pm 0.3$ & $2.3 \pm 0.7$ \\
\hline \multirow[t]{3}{*}{$7 / 23$} & BS & 16.1 & $0.05 \pm 0.02$ & $3.7 \pm 2.6$ & $0.7 \pm 0.2$ & $2.5 \pm 0.2$ & $3.5 \pm 0.1$ & $52.7 \pm 6.4$ \\
\hline & VS & & $0.01 \pm 0.00$ & $0.2 \pm 0.1$ & $0.1 \pm 0.0$ & $0.4 \pm 0.1$ & $1.0 \pm 0.3$ & $1.5 \pm 0.9$ \\
\hline & $\mathrm{GC}$ & & $0.00 \pm 0.00$ & - & - & - & - & - \\
\hline \multirow[t]{3}{*}{$8 / 15$} & BS & 36 & $0.80 \pm 0.52$ & $238.4 \pm 154.0$ & $2.5 \pm 1.3$ & $4.9 \pm 2.9$ & $7.7 \pm 4.5$ & $304.1 \pm 277.5$ \\
\hline & VS & & $0.03 \pm 0.02$ & $0.7 \pm 0.2$ & $0.1 \pm 0.0$ & $0.2 \pm 0.0$ & $0.8 \pm 0.2$ & $28.9 \pm 0.4$ \\
\hline & $\mathrm{GC}$ & & $0.00 \pm 0.00$ & - & - & - & & \\
\hline \multirow[t]{3}{*}{$8 / 19$} & $\mathrm{BS}$ & 34.7 & $1.04 \pm 0.60$ & $30.5 \pm 18.1$ & $4.0 \pm 1.9$ & $5.1 \pm 1.5$ & $5.5 \pm 2.9$ & $224.0 \pm 114.3$ \\
\hline & VS & & $0.04 \pm 0.02$ & $0.9 \pm 0.6$ & $0.5 \pm 0.1$ & $0.2 \pm 0.0$ & $0.4 \pm 0.1$ & $30.3 \pm 15.2$ \\
\hline & $\mathrm{GC}$ & & $0.00 \pm 0.00$ & - & - & - & - & - \\
\hline \multirow[t]{3}{*}{ Total } & BS & 182 & 3.24 & 1034.1 & 19.2 & 19.9 & 42.3 & 637.0 \\
\hline & VS & & 0.26 & 4.5 & 4.0 & 2.3 & 7.7 & 83.6 \\
\hline & $\mathrm{GC}$ & & 0.03 & 0.4 & 3.9 & 0.3 & 5.3 & 3.4 \\
\hline \multicolumn{9}{|l|}{2010} \\
\hline $6 / 18$ & BS & 53.5 & $1.00 \pm 0.07$ & $214.1 \pm 13.0$ & $4.0 \pm 2.6$ & $5.3 \pm 3.4$ & $12.5 \pm 6.1$ & $48.6 \pm 5.6$ \\
\hline $6 / 24$ & $\mathrm{BS}$ & 108.7 & $1.30 \pm 0.08$ & $1769.7 \pm 98.4$ & $15.3 \pm 4.9$ & $6.7 \pm 0.8$ & $26.5 \pm 7.9$ & $208.8 \pm 29.6$ \\
\hline $7 / 6$ & BS & 32.1 & $2.03 \pm 0.28$ & $1459.4 \pm 895.8$ & $16.2 \pm 7.8$ & $12.3 \pm 5.2$ & $28.5 \pm 13.5$ & $87.2 \pm 55.99$ \\
\hline Total & & 194.3 & 4.33 & 3443.2 & 35.5 & 24.3 & 67.5 & 344.6 \\
\hline
\end{tabular}

vegetation (GC and VS) did not generate detectable runoff in any of these three rainfall events. Even though there were fewer rainfall events than in 2009 , the BS plots generated higher volumes of runoff and soil losses in 2010 than in the previous years (Table 2). Runoff volumes in the BS plots increased throughout the rainy season in 2010, and the largest runoff occurred in the last rainfall event of that year, with an average across all BS plots of $2 \mathrm{~mm}$. The most soil loss was observed in the second rainfall of 2010 after $109 \mathrm{~mm}$ of precipitation, with an average soil loss from BS plots of $1769.7 \mathrm{kgha}^{-1}$. Nutrient concentrations and losses in runoff also increased throughout the rainy season that year. The greatest nutrient losses in runoff occurred during the last rainfall event of
2010 , with total losses of $16.2,12.3$ and $28.5 \mathrm{gha}^{-1}$ of inorganic- $\mathrm{N}, \mathrm{PO}_{4}-\mathrm{P}$, and $\mathrm{TN}$, respectively-the highest nutrient losses observed for an individual storm during this entire study (Table 2).

\section{Herbicide residues}

The average concentrations of terbuthylazine in the runoff water from the BS plots were 55.4, 79.9, and $64.2 \mu \mathrm{gL}^{-1}$ in 2008, 2009 and 2010, respectively. The herbicide concentrations were highest in the runoff event following the annual herbicide application, with concentrations as high as 487.2, 260.4 and $388.3 \mu \mathrm{g}$ $\mathrm{L}^{-1}$ in 2008, 2009 and 2010, respectively. Even though terbuthylazine was applied only in the BS 
plots, traces of that herbicide were detected in all treatment runoff samples, though in a much lower concentrations than in the BS plots. During 2008 and 2009 , the average concentrations of terbuthylazine in runoff water from the VS and GC plots were 15.4 and $5.3 \mu \mathrm{gL}^{-1}$, respectively.

Soil physical properties and nutrient availability

There were substantial differences in soil physical properties among treatments from 2009 to 2011. Soil bulk density $\left(\mathrm{g} \mathrm{cm}^{-3}\right)$ was greater in the BS plots than in the GC plots (Table 3). Soil macro-porosity and aggregate stability were significantly higher in the GC plots than in the other two treatments.

There were sustained trends in the relative availability of essential plant nutrients in soil among treatments during 3 years of observations (Table 4). Soil K and $\mathrm{Mg}$ availability, and soil $\mathrm{pH}$ were significantly higher in GC than in the BS treatment. On the contrary, $\mathrm{Zn}$ concentrations were significantly higher in the BS plots than in the GC treatment. The GC plots had significantly higher soil $\mathrm{pH}$, and $\mathrm{P}, \mathrm{K}$, and $\mathrm{Cu}$ concentrations than the VS plots. Soil organic matter (SOM) and total C content were significantly different among treatments; the highest SOM content was observed in the GC plots, followed by the VS and BS treatments. Total $\mathrm{N}$ was significantly higher in soil of GC plots than in the other two treatments, and C-to-N ratios were significantly lower in BS than in the VS and GC treatments. There were no significant differences observed among treatments for soil $\mathrm{Ca}, \mathrm{Fe}, \mathrm{Al}$, $\mathrm{Mn}$ and $\mathrm{NO}_{3}-\mathrm{N}$ availability during this study.

Trends in water content from 2009 to 2011 were complex and varied among years as well as among treatments. Soil water content was different among all three treatments $(P<0.0001)$, with average soil water contents ranking $\mathrm{GC}>\mathrm{VS}>\mathrm{BS}$ during the time span of this study.

\section{Discussion}

Groundcover competition with tree growth

Short-term studies comparing different groundcover management systems have shown that competition for nutrients and water between weeds or mowed sod covers and fruit trees can cause substantial growth

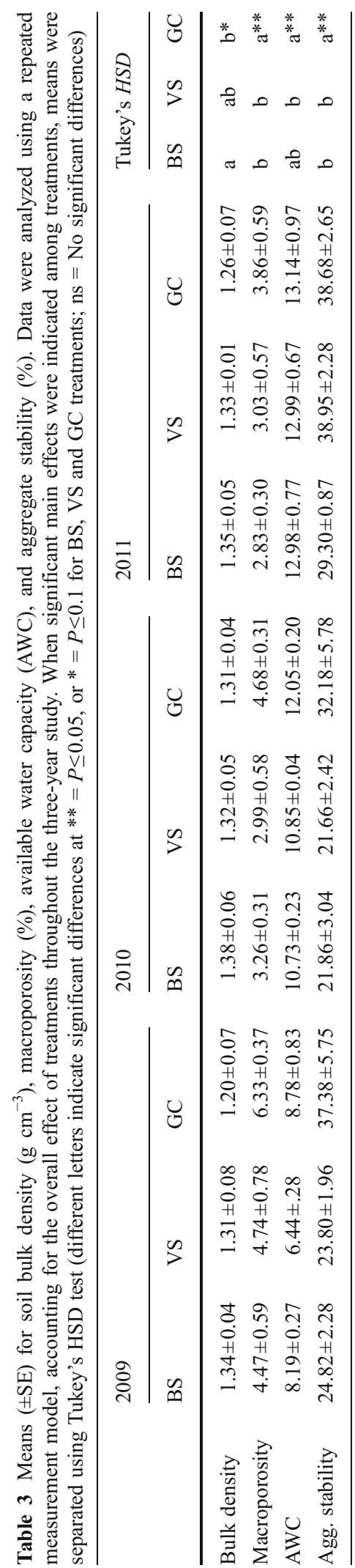




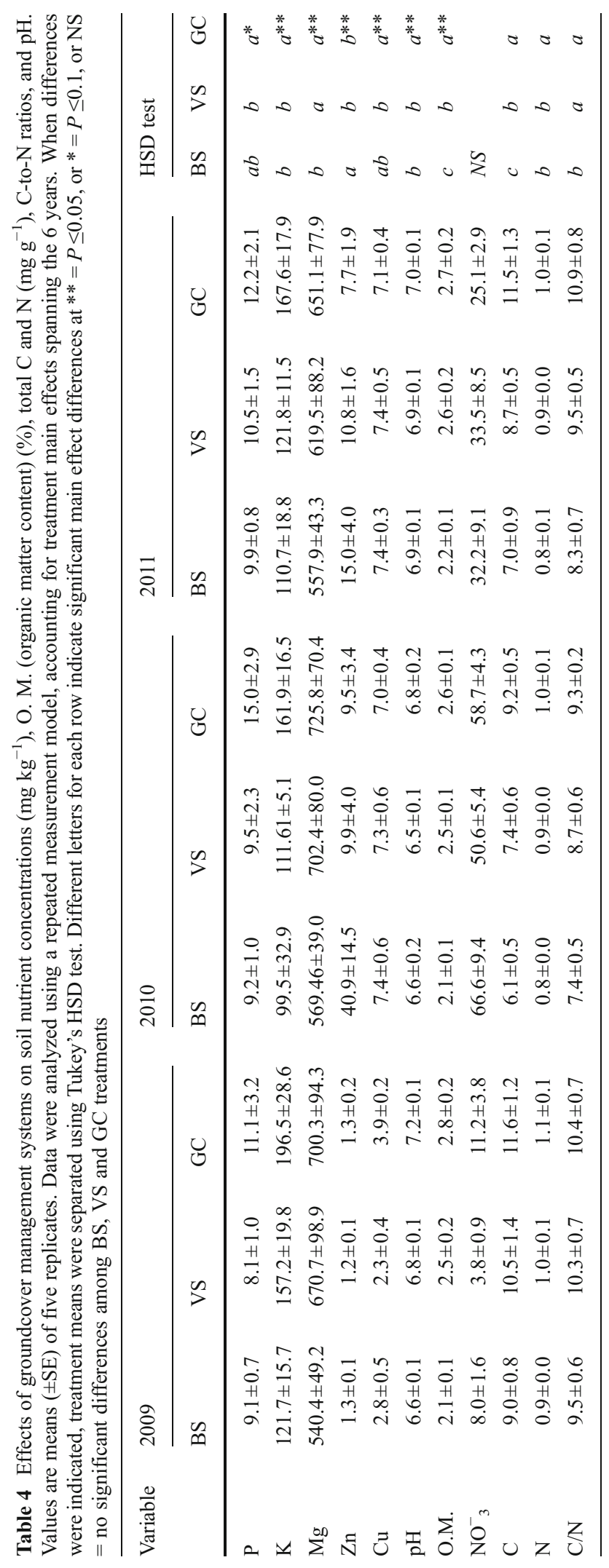


reductions and yield losses, in comparison with weedfree groundcover management systems. As previously reported by others (Robinson and O'Kennedy 1978; Shribbs and Skorch 1986; Welker and Glenn 1989), we also observed reduced tree growth and fruit yield in the GC compared with BS plots. However, in our study soil water contents in GC plots were actually greater than those in the BS plots, suggesting that trees in the GC and VS treatments were not experiencing more water stress than BS trees. Moreover, leaf nutrient contents were not significantly different among treatments, which suggests that trees in the VS or GC plots were not more stressed than BS trees by nutrient deficiencies. In addition, total soil $\mathrm{N}$ and $\mathrm{C}$ contents were greater in the GC than in the BS treatments, probably due to $\mathrm{C}$ input from groundcover residues and $\mathrm{N}_{2}$ fixation by the Hualputra legume groundcover (Ovalle et al. 2006; Nyborg et al. 1995b; Janzen et al. 1998; Solberg et al. 1998; Kumar and Goh 1999). However, during decomposition of cover crop residues there may be an initial period of soil N-immobilization, followed by a period of net N re-mineralization (Kumar and Goh 1999; Recous et al. 1999). The duration of this period depends on the C-to-N ratios of the crop residue (Reinertsen et al. 1984), lignin and polyphenol contents (Kumar and Goh 1999), and initial soil N concentrations (Reinertsen et al. 1984; Recous et al. 1995), among other factors. In the present study, uptake of $\mathrm{N}$ by groundcovers, retention of $\mathrm{N}$ during initial groundcover residue decomposition, and the low initial soil organic matter content at this site, could have interacted to reduce soil $\mathrm{N}$ availability transiently in the GC and VS plots compared with the BS treatment (Nyborg et al. 1995a). This temporary restriction in soil $\mathrm{N}$ availability may explain the decreased growth and fruit yield of trees in the VS and GC treatments compared to BS.

Additionally, even though groundcovers are relatively more efficient than fruit trees in recycling $\mathrm{N}$ mineralized by decomposing groundcover residues (Haynes and Goh 1980; Sanchez et al. 2003; Yao et al. 2005), during the first years of our study there were minimal groundcover residues to be recycled, and the groundcover vegetation was directly competing for nutrients and water with the newly planted avocado trees. This initial competition, at a vulnerable stage for the newly planted avocado trees, might have been masked in the overall effects of groundcover management on soil moisture and leaf nutrient contents, but it could have been enough to affect tree growth. Although we did not directly measure above-ground biomass of the avocado trees, those in the BS plots were bigger than those in the groundcover treatments, but they had similar foliar N concentrations. This suggests a greater total $\mathrm{N}$ uptake by trees in the BS plots, probably because $\mathrm{N}$ was less available in $\mathrm{GC}$ and VS than in BS plots. Other factors such as tree-groundcover root competition could have also resulted in tree growth reductions and yields losses in the groundcover plots (McMurtrie and Wolf 1983).

Welker and Glenn (1989) observed that growth of young peach (Prunus persica) trees was proportional to the surrounding vegetation-free area, suggesting that restriction in soil volume due to sod competition resulted in smaller peach root systems and consequentially smaller trees. However, in our study the growth of trees in both the GS and the VS plots was equivalently reduced, despite the closer groundcover proximity to avocado trees in the GC than in VS treatments. In this context it is also noteworthy that the winters where evergreen fruit trees are cultivated are generally warmer than those where deciduous fruit trees are grown. The warmer temperatures during humid winter months, and irrigation during the drier summer months (November through March) at our site in Chile, allowed for continuous growth of weeds and groundcovers throughout the year in our study. These conditions presumably increased competition between groundcover vegetation and newly established avocado trees, and yearly post-emergence herbicide application in the VS treatment may have not been sufficient to eliminate weed competition. Similar effects on tree growth and fruit yield were observed by Castro and Pastor (1994) and Wright et al. (2003) in a groundcover management systems studies in an olive grove and citrus orchard, respectively.

The use of groundcovers as an alternative groundcover management system for hillside avocado orchards had negative effects on tree growth and productivity during the first 3 years after orchard establishment. These economic downsides partly explain the reluctance of avocado growers to change their soil management practices. However, long-term studies of alternative groundcover management systems in other orchard crops have shown that continued interactions of fruit trees with competing groundcover vegetation enables trees to adapt and compensate or avoid 
groundcover competition for water and nutrients (Atucha et al. 2011a, b). Furthermore, the long-term deterioration of soil physical conditions and biological activity in weed-free orchard soils (Oliveira and Merwin 2001; Yao et al. 2005) may eventually be more detrimental for orchard productivity than the short-term groundcover competition during initial orchard establishment.

\section{Mitigation of nutrient losses}

Previous studies have shown that groundcovers can provide runoff and soil erosion control in perennial fruit plantings on hillsides (Francia Martinez et al. 2006; Garcia-Orenes et al. 2009; Gomez et al. 2003; Martinez Raya et al. 2006; Youlton et al. 2010). The interception of rainfall by groundcovers dissipates the impact of raindrops on the soil surface, ultimately reducing runoff and erosion (Francia Martinez et al. 2006). We observed a significant reduction in runoff and erosion in both groundcover treatments compared to the bare soil treatment, and similar observations were reported by Youlton et al. (2010) and Francia Martinez et al. (2006), in avocado and olive orchards under different groundcover treatments.

During 2008, before the establishment of treatments in our study, runoff volumes increased and erosion rates decreased throughout the wet season. The high erosion rates observed at the beginning of the rainy season in 2008 suggest a high vulnerability of the newly constructed berms to rainfall, as a consequence of the disturbance of the soil during excavation in the swales and mounding up the berms. On the other hand, the increased runoff toward the end of the wet season in 2008 probably resulted from soil compaction and surface crusting due to preceding rain events that year, leading to soil-surface sealing that reduced infiltration and increased runoff (Lindstrom and Onstad 1984; Gomez et al. 1999, 2004). Saturated soil conditions at the end of winter in 2008 might also have reduced infiltration and increased runoff compared to the initial rainfall events that year (Bissonnais et al. 1995). These results highlight the importance of protecting soil from erosive forces after the construction of berms and during hillside orchard establishment, the period when soil is most vulnerable to erosion due to its recent disturbance, and lack of surface vegetation and crop residues.
Soil compaction in the BS plots was greater than in the GC treatment, as reflected by the higher soil bulk density and lower macro-porosity in the BS compared to the GC plots (Table 3). Soil management effects on aggregate stability influence susceptibility to soil degradation, and are fundamental for promoting soil conservation (Boix-Fayos et al. 2001; Ramos et al. 2010). In our study, aggregate stability increased in soil beneath groundcovers. Organic substances supplied by roots are a source of energy for microorganisms in the rhizosphere, and materials produced by these microorganisms (e.g. mucilaginous polysaccharides) play an important role in the stabilization of soil aggregates (Gale et al. 2000; Six et al. 2004; Ramos et al. 2010). In addition, soil organic matter content, which has been extensively correlated with aggregate stability (Oades 1984; Caravaca et al. 2002; Ramos et al. 2010), probably contributed to the greater aggregate stability observed in the GC plots, which likely reduced runoff volumes and soil erosion in that treatment.

The increased soil organic matter content in GC and VS plots, attributed to groundcover residues and rhizosphere decomposition (Manns et al. 2007), improved soil fertility and soil physico-chemical conditions, facilitating soil-water storage during the summer months. The assimilation of $\mathrm{N}$ and $\mathrm{P}$ from fertilizers and $\mathrm{N}_{2}$ fixation by the groundcover into microbial biomass and stable forms of soil organic matter probably reduced losses through surface runoff in the GC and VS in comparison to the BS plots.

Mitigation of water quality impacts using groundcovers

Total nutrient losses in our study were lower than those reported in other studies for perennial fruit crops (Ramos and Martinez-Casasnovas 2004, 2006; Francia Martinez et al. 2006; Duran Zuazo et al. 2004). However, $\mathrm{NH}_{4}-\mathrm{N}$ concentrations exceeded both the $0.5 \mathrm{mgL}^{-1}$, threshold concentration for public water supplies (Hütter 1994), and the $5 \mathrm{mgL}^{-1}$ limit for irrigation sources (Ayers et al. 1985) during the first rainfall events of 2009.

Average $\mathrm{PO}_{4}-\mathrm{P}$ concentrations in most runoff events in all our treatments exceeded established limits of $0.05 \mathrm{mgL}^{-1}$ (US-EPA 1976) that may lead to eutrophication of surface waters. The P concentrations in runoff remained below the critical threshold level of $2 \mathrm{mgL}^{-1}$ for agricultural water use (Ayers et al. 1985). However, since total nutrient losses were estimated 
based on dissolved nutrients in runoff water, our results probably underestimated the total amounts of nutrients lost, because we did not account for nutrients bound to soil in particulate forms. Particulate $\mathrm{P}$ can account for $75-95 \%$ of the $\mathrm{P}$ losses in runoff water from agricultural land, according to reports that $\mathrm{P}$ losses in sediment transport were 2.8 fold higher than those dissolved in runoff water (Sharpley et al. 1994; Duran Zuazo et al. 2004).

Considering water quality, the average terbuthylazine concentrations in surface BS treatment runoff water during this study (55.4 to $79.9 \mu \mathrm{gL}^{-1}$ ) were substantially higher than the guideline values for pesticide residues in drinking water, set at $7 \mu \mathrm{gL}^{-1}$ for terbuthylazine (Younes and Galal-Gorchev 2000), and the European Union maximum level of $0.1 \mu \mathrm{gL}^{-1}$ in water intended for human consumption (Hamilton et al. 2003). Terbuthylazine can also be transported through sediments, due to its moderate sorption and a relatively long persistence in soils (Blanchoud et al. 2007), increasing the risk of water contamination and bioaccumulation in aquatic organisms (FCS 2007). The concentrations of this herbicide in runoff from our site are therefore a real concern for this region of Chile.

\section{Conclusion}

Our study demonstrated substantial impacts of groundcover management systems on soil erosion and runoff in newly planted hillside avocado orchards under natural rainfall conditions, and suggests the potential for protecting these hillsides by managing groundcovers to reduce erosion and associated environmental problems. One year after the establishment of the orchards, soil erosion, runoff, and nutrient losses were reduced with groundcover, in comparison with the bare soil. Deterioration of soil physical properties- higher soil bulk density and lower macroporosity and soil aggregate stability- were observed without groundcover, which in the long-term might be more detrimental and unsustainable for orchard productivity than the initial short-term groundcover competition. The high concentration of triazine-type herbicide residues detected in the runoff water from bare soil plots presents a significant risk of contamination of drinking water sources. Future research should focus on the impact these steep hillside orchards have at the watershed scale.
Acknowledgments The author would like to express their appreciation to Towards Sustainability Foundation for the financial support, and to Jorge Schmidt for providing the site and maintenances of this project.

Open Access This article is distributed under the terms of the Creative Commons Attribution License which permits any use, distribution, and reproduction in any medium, provided the original author(s) and the source are credited.

\section{References}

Atucha A, Merwin IA, Brown MG (2011a) Long-term effects of four groundcover management systems in an apple orchard. HortScience 46(8):1176-1183

Atucha A, Merwin IA, Purohit CK, Brown MG (2011b) Nitrogen dynamics and nutrient budgets in four orchard groundcover management systems. HortScience 46(8):1184-1193

Ayers RS, Westcot DW, Food and Agriculture Organization of the United Nations (1985) Water quality for agriculture. Irrigation and drainage paper, vol 29 rev. 1. Food and Agriculture Organization of the United Nations, Rome

Bissonnais Y, Renaux B, Delouche H (1995) Interactions between soil properties and moisture content in crust formation, runoff and interrill erosion from tilled loess soils. Catena 25(1/4):33-46

Blanchoud H, Moreau-Guigon E, Farrugia F, Chevreuil M, Mouchel JM (2007) Contribution by urban and agricultural pesticide uses to water contamination at the scale of the Marne watershed. Sci Total Environ 375(1/3):168-179

Boix-Fayos C, Calvo-Cases A, Imeson AC, Soriano-Soto MD (2001) Influence of soil properties on the aggregation of some Mediterranean soils and the use of aggregate size and stability as land degradation indicators. Catena 44(1):4767

Braun AL, Hawkins LS (1991) Presence of Bromacil, Diuron, and Simazine in Surface Water Runoff from Agricultural Fields and Non-Crop Sites in Tulare County, California. Environmental Monitoring and Pest Management Branch, California Department of Pesticide Regulation, Sacramento

Caravaca F, Hernandez T, Garcia C, Roldan A (2002) Improvement of rhizosphere aggregate stability of afforested semiarid plant species subjected to mycorrhizal inoculation and compost addition. Geoderma 108(1-2):133-144

Castro J, Pastor M (1994) El empleo de una cubierta viva de cebada. Agric Rev Agropecuaria 63:754-758

Cerda A, Gimenez Morera A, Bodi MB (2009) Soil and water losses from new citrus orchards growing on sloped soils in the western Mediterranean basin. Earth Surf Process Landf 34(13):1822-1830

Clesceri LS, Greenberg AE, Eaton AD (1998) Standard methods for the examination of water and wastewater. Wash., DC

CONAMA (2006) Estudio de la variabilidad climática en Chile para el siglo XXI. Comisión Nacional del Medio Ambiente, Santiago, Chile

Duran Zuazo VH, Martinez Raya A, Aguilar Ruiz J (2004) Nutrient losses by runoff and sediment from the taluses of orchard terraces. Water Air Soil Pollut 153(1/4):355-373 
FCS (2007) Forest Stewardship Council pesticides policy: guidance on implementation. http://www.fsc.org Accessed January 2012

Francia Martínez J, Martínez Raya A, Ruíz Gutiérrez S (2000) Erosión en suelos de olivar en fuertes pendientes. Comportamiento de distintos manejos de suelo. Edafología 7:147-155

Francia Martinez JR, Duran Zuazo VH, Martinez Raya A (2006) Environmental impact from mountainous olive orchards under different soil-management systems (SE Spain). Sci Total Environ 358(1/3):46-60

Gale WJ, Cambardella CA, Bailey TB (2000) Root-derived carbon and the formation and stabilization of aggregates. Soil Sci Soc Am J 64(1):201-207

Garcia-Orenes F, Cerda A, Mataix-Solera J, Guerrero C, Bodi MB, Arcenegui V, Zornoza R, Sempere JG (2009) Effects of agricultural management on surface soil properties and soil-water losses in eastern Spain. Soil Tillage Res 106 (1):117-123

Gardiazabal F (1998) Factores agronómicos a considerar en la implantación de un huerto de paltos. Seminario Internacional de Paltos. Sociedad Gardiazabal y Magdhal Ltda, Viña del Mar, Chile, pp 17-37

Gasto J, Gallardo S, Contreras D (1987) Caracterización de los pastizales de Chile: reinos, dominios y provincias. Pontificia Universidad Católica de Chile, Santiago, Chile

Geo-Chile (2005) Informe País: Estado del medio ambiente en Chile 2005. Universidad de Chile. http://www.scribd.com/ doc/33742067/Informe-pais-estado-del-medio-ambiente-enChile-2005. Accessed 29 June 2011

Glotfelty DE, Taylor AW, Isensee AR, Jersey J, Glenn S (1984) Atrazine and simazine movement to Wye river estuary. J Environ Qual 13(1):115-121

Gomez JA, Giraldez JV, Pastor M, Fereres E (1999) Effects of tillage method on soil physical properties, infiltration and yield in an olive orchard. Soil Tillage Res 52(3/4):167-175

Gomez JA, Battany M, Renschler CS, Fereres E, International BIC (2003) Evaluating the impact of soil management on soil loss in olive orchards. Soil Use Manag 19(2):127-134

Gomez JA, Romero P, Giraldez JV, Fereres E (2004) Experimental assessment of runoff and soil erosion in an olive grove on a Vertic soil in southern Spain as affected by soil management. Soil Use Manag 20(4):426-431

Hamilton DJ, Ambrus A, Dieterle RM, Felsot AS, Harris CA, Holland PT, Katayama A, Kurihara N, Linders J, Unsworth J, Wong SS (2003) Regulatory limits for pesticide residues in water (IUPAC Technical Report). Pure Appl Chem 75 (8):1123-1155

Haynes RJ, Goh KM (1980) Some effects of orchard soil management on sward composition, levels of available nutrients in the soil, and leaf nutrient content of mature 'Golden Delicious' apple trees. Sci Hortic 13(1):15-25

Hütter LA (1994) Wasser und Wasseruntersuchung: Methodik, Theorie und Praxis chemischer, chemisch-physikalischer, biologischer und bakteriologischer Untersuchungsverfahren. Salle; Sauerländer, Frankfurt am Main, Aarau, Frankfurt am Main, Salzburg

Janzen HH, Campbell CA, Izaurralde RC, Ellert BH, Juma N, McGill WB, Zentner RP (1998) Management effects on soil C storage on the Canadian prairies. Soil Tillage Res 47 (3/4):181-195
Karunatilake UP, van Es HM (2002) Rainfall and tillage effects on soil structure after alfalfa conversion to maize on a clay loam soil in New York. Soil Tillage Res 67(2):135-146

Kosmas CS, Moustakas N, Danalatos NG, Yassoglou N (1996) The Sparta field site: I. The impacts of land use and management on soil properties and erosion. II. The effect of reduced moisture on soil properties and wheat production. Mediterranean desertification and land use. John Wiley \& Sons Ltd, Chichester UK

Kumar K, Goh KM (1999) Crop residues and management practices; effects on soil quality, soil nitrogen dynamics, crop yield and nitrogen recovery. Adv Agron 68:197-319

Lahav E, Whiley AW (2002) Irrigation and mineral nutrition. In: Whiley AW, Schaffer B, Wolstenholme BN (eds) The avocado: botany, production and uses. CABI, New York, pp 259-298

Leonard RA (1990) Movement of pesticides into surface waters. In: Chend $\mathrm{HH}$ (ed) Pesticides in the soil environment: processes, impacts, and modeling. Soil Science Society of America, Madison, pp 303-349

Lindstrom MJ, Onstad CA (1984) Influence of tillage systems on soil physical parameters and infiltration after planting. $\mathrm{J}$ Soil Water Conserv 39(2):149-152

Manns HR, Maxwell CD, Emery RJN (2007) The effect of ground cover or initial organic carbon on soil fungi, aggregation, moisture and organic carbon in one season with oat (Avena sativa) plots. Soil Tillage Res 96(1-2):83-94

Martinez Raya A, Duran Zuazo VH, Francia Martinez JR (2006) Soil erosion and runoff response to plant-cover strips on semiarid slopes (SE Spain). Land Degrad Dev 17(1):1-11

McMurtrie R, Wolf L (1983) A model of competition between trees and grass for radiation, water and nutrients. Ann Bot 52(4):449-458

Moebius BN, van Es HM, Schindelbeck RR, Idowu OJ, Clune DJ, Thies JE (2007) Evaluation of laboratory-measured soil properties as indicators of soil physical quality. Soil Sci 172(11):895-912

Moebius-Clune BN, van Es HM, Idowu OJ, Schindelbeck RR, Moebius-Clune DJ, Wolfe DW, Abawi GS, Thies JE, Gugino BK, Lucey R (2008) Long-term effects of harvesting maize stover and tillage on soil quality. Soil Sci Soc Am J 72(4):960-969

Novara A, Gristina L, Saladino SS, Santoro A, Cerda A (2011) Soil erosion assessment on tillage and alternative soil managements in a Sicilian vineyard. Soil Tillage Res 117:140-147

Nyborg M, Solberg ED, Izaurralde RC, Malhi SS, Molina-Ayala M (1995a) Influence of long-term tillage, straw and $\mathrm{N}$ fertilizer on barley yield, plant-N uptake and soil-N balance. Soil Tillage Res 36(3/4):165-174

Nyborg M, Solberg ED, Malhi SS, Izaurralde RC (1995b) Fertilizer $\mathrm{N}$ crop residue and tillage alter soil organic carbon and nitrogen content in a decade. In: Lal R, Kimble J, Levine E, Stewart BA (eds) Soil management and greenhouse effects. Adv. Soil Sci. CRC Press Inc., Boca Raton, FL, pp 93-99

Oades JM (1984) Soil organic-matter and structural stabilityMechanisms and implications for management. Plant and Soil 76(1-3):319-337

Ogden CB, van Es HM, Schindelbeck RR (1997) Miniature rain simulator for field measurement of soil infiltration. Soil Sci Soc Am J 61(4):1041-1043 
Oliveira MT, Merwin IA (2001) Soil physical conditions in a New York orchard after eight years under different groundcover management systems. Plant and Soil 234(2):233237

Ovalle C, Urquiaga S, Pozo A, Zagal E, Arredondo S (2006) Nitrogen fixation in six forage legumes in Mediterranean central Chile. Acta Agric Scand Sect B Plant Soil Sci 56(4):277-283

Pimentel D, Harvey C, Resodudarmo P, Sinclair K, Kurz D, McNair M, Crist S, Shpritz L, Fitton L, Saffouri R, Blair R (1995) Environmental and economic costs of soil erosion and conservation benefits. Science (Washington) 267(5201):1117-1123

Ramos MC, Martinez-Casasnovas JA (2004) Nutrient losses from a vineyard soil in Northeastern Spain caused by an extraordinary rainfall event. Catena 55(1):79-90

Ramos MC, Martinez-Casasnovas JA (2006) Erosion rates and nutrient losses affected by composted cattle manure application in vineyard soils of NE Spain. Catena 68(2-3):177-185

Ramos ME, Benitez E, Garcia PA, Robles AB (2010) Cover crops under different managements vs. frequent tillage in almond orchards in semiarid conditions: Effects on soil quality. Appl Soil Ecol 44(1):6-14

Recous S, Robin D, Darwis D, Mary B (1995) Soil inorganic N availability: effect on maize residue decomposition. Soil Biol Biochem 27(12):1529-1538

Recous S, Aita C, Mary B (1999) In situ changes in gross N transformations in bare soil after addition of straw. Soil Biol Biochem 31(1):119-133

Reinertsen MR, Cochran VL, Morrow LA (1984) Response of spring wheat to $\mathrm{N}$ fertilizer placement, row spacing, and wild oat herbicides in a no-till system. Agron J 76(5):753-756

Robinson DW, O'Kennedy ND (1978) The effect of overall herbicide systems of soil management on the growth and yield of apple trees 'Golden Delicious'. Sci Hortic 9(2):127-136

Sanchez JE, Edson CE, Bird GW, Whalon ME, Willson TC, Harwood RR, Kizilkaya K, Nugent JE, Klein W, Middleton A, Loudon TL, Mutch DR, Scrimger J (2003) Orchard floor and nitrogen management influences soil and water quality and tart cherry yields. J Am Soc Hortic Sci 128(2):277-284

Sharpley AN, Chapra SC, Wedephol R, Sims JT, Daniel TC, Reddy KR (1994) Managing agricultural phosphorus for protection of surface waters: issues and options. J Environ Qual 23(3):437-451

Shribbs JM, Skorch WA (1986) Influence of 12 ground cover systems on young "smoothee golden delicious"apple trees: II. Nutrition. J Am Soc Hortic Sci 111:529-533
Simmons SE, Leyva JJ (1994) Presence of soil-applied herbicides in three rights-of-way infiltration basins in San Joaquin county. Environmental monitoring and pest management branch. California Department of Pesticide Regulation, Sacramento, CA

Sims JT, Simard RR, Joern BC (1998) Phosphorus loss in agricultural drainage: historical perspective and current research. J Environ Qual 27(2):277-293

Six J, Bossuyt H, Degryze S, Denef K (2004) A history of research on the link between (micro)aggregates, soil biota, and soil organic matter dynamics. Soil Tillage Res 79(1):7-31

Solberg ED, Nyborg M, Izaurralde RC, Malhi SS, Janzen HH, Molina-Ayala M (1998) Carbon storage in soils under continuous cereal grain cropping: $\mathrm{N}$ fertilizer and straw. In: Lal R, Kimble J, Follett RF, Stewart BA (eds) Management of carbon sequestration in soil. Lewis Publishers, Boca Raton, pp 235-254

Toscano P, Briccoli-Bati C, Godino G, Simone C, Ragliones M, Lorenzoni P, Angelini R, Antonuccio S (2004) Agronomic and pedological effects of two systems of ground management in a hill olive grove in southern Italy. Oliva 102:21-26

Tropeano D (1983) Soil erosion on vineyards in the Tertiary Piedmontese basin (northwestern Italy): studies on experimental areas. Catena Suppl 4:115-127

US-EPA (1976) Quality criteria for water. US Environmental Protection Agency, Washington, D.C.

Uson A, Espinosa E, Poch RM (1998) Effectivity of soil conservation practices in vineyard soils from Catalonia region, Spain. Int Agrophys 12(3):155-165

Welker WV, Glenn DM (1989) Sod proximity influences the growth and yield of young peach trees. J Am Soc Hortic Sci 114(6):856-859

Wright GC, McCloskey WB, Taylor KC (2003) Managing orchard floor vegetation in flood-irrigated citrus groves. HortTech 13(4):668-677

Yao SR, Merwin IA, Bird GW, Abawi GS, Thies JE (2005) Orchard floor management practices that maintain vegetative or biomass groundcover stimulate soil microbial activity and alter soil microbial community composition. Plant and Soil 271(1/2):377-389

Youlton C, Espejo P, Biggs J, Norambuena M, Cisternas M, Neaman A, Salgado E (2010) Quantification and control of runoff and soil erosion on avocado orchards on ridges along steep-hillslopes. Cienc Investig Agrar 37(3):113-123

Younes M, Galal-Gorchev H (2000) Pesticides in drinking water - a case study. Food Chem Toxicol 38(Supplement 1):S87-S90 